DOI https://doi.org/10.33766/2524-0323.86.258-269

УДК 343.322

О. В. Зайцев,

кандидат юридичних наук, доцент, доцент кафедри кримінального права №1 Національного юридичного університету імені Ярослава Мудрого

(м. Харків, Україна)

e-mail: tavr0106@gmail.com

iD https://orcid.org/0000-0002-6743-7114

\title{
ДО ПРОБЛЕМИ КВАЛІФІКАЦІЇ ДЕРЖАВНОЇ ЗРАДИ У РАЗІ ПЕРЕХОДУ НА БІК ВОРОГА В ПЕРІОД ЗБРОЙНОГО КОНФЛІКТУ (АНАЛІЗ СУДОВОЇ ПРАКТИКИ 2014-2018 РР.)
}

Статтю присвячено дослідженню проблеми кваліфікації державної зради у разі переходу на бік ворога в період збройного конфлікту. У роботі вивчено судову практику за 2014-2018 рр. Зроблено висновок про різну законодавчу оцінку окупації Автономної Республіки Крим та окремих районів Донецької та Луганської областей. Обгрунтована різна кримінально-правова кваліфікація дій громадян по переходу на бік ворога під час цих збройних конфліктів. Акцентується увага на висновках, які містяться в звітах за результатами попереднього розслідування подій у Криму та на сході України, що оприлюднені в 2016р. та 2018 р. Канцелярією Прокурора Міжнародного кримінального суду.

Ключові слова: перехід на бік ворога, збройний конфлікт, Міжнародний кримінальний суд.

Постановка проблеми. Кримінальне провадження за ст. 111 КК України за роки незалежності України було вкрай рідкісним явищем. Так за повідомленням СБУ в період 2001-2011 рр. в провадженні перебувало всього 17 кримінальних справ. У чотирьох із них засуджено сім осіб [1].

Після Революції Гідності в лютому 2014 р. наша держава перейшла до етапу, який характеризується значною кількістю факторів, як зовнішніх, так і внутрішніх, що загрожують іï суверенності, незалежності, національній безпеці. Конфлікти в Автономній Республіці Крим, Донецькій та Луганській областях змінили не тільки геополітику у світі, а й безпосередньо вплинули на громадян України. Зокрема, якщо за весь 2013 рік Генеральною прокуратурою України обліковано лише одне кримінальне провадження за ознаками державної зради, то у 2014 р. таких проваджень було 65, у 2015 - 89 [2], а за 2018p. у Сдиному звіті про кримінальні правопорушення обліковано вже 127 злочинів, передбачених ст. 111 КК України [3]. Зазначене зростання кількості проваджень, що розслідуються, стали підставою для змін КК України (у квітні та жовтні 2014 р.) в частині збільшення міри покарання для осіб, які вчинили цей злочин. Зауважимо, що ці законодавчі зміни не зупинили зростання кількості кримінальних проваджень за ст.111 КК України в подальші роки.

(C) Зайцев О. В., 2019 
Аналіз останніх досліджень і публікацій. Дослідженням кримінальної відповідальності за державну зраду займались такі науковці, як: Г. З. Анашкін, Г. В. Андрусів, О. Ф. Бантишев, Ю. В. Баулін, В. М. Боровенко, В. А. Владіміров, Н. С. Кончук, В. Г. Кундеус, Ю. В. Луценко, В. Я. Тацій, М. І. Хавронюк, П. В. Хряпінський, В. М. Шамара та інші.

Формування цілей. Метою статті є 3'ясування проблем правозастосовної практики із кваліфікації дій громадян України по переходу на бік ворога під час збройного конфлікту, аналіз доступної судової практики застосування ст. 111 КК України за 2014-2018 рр.

Виклад основного матеріалу. Сдиний державний реєстр судових рішень України містить інформацію про 57 вироків за ст.111 КК України, які винесені за період із 2014 р. по 2018 р. Зазначимо, що обвинувальні вироки при переході на бік ворога стосуються тільки випадків вчинення злочину в період збройного конфлікту України та Російської Федерації на території Автономної Республіки Крим. Значна їх частина була або ще перебуває на стадії апеляційного чи касаційного оскарження. Основним доводом у скаргах осіб, які є обвинуваченими в державній зраді у формі переходу на бік ворога, $є$ вказівка на відсутність військового конфлікту або завершення періоду його існування. Зокрема свої скарги захисники обгрунтовують тим, що «суд вбачає в діях осіб перехід на бік ворога у період збройного конфлікту, проте наявність збройного конфлікту та його тривалість (де конкретно мало місце поле бою - збройного (воєнного) конфлікту, хто є у ньому ворогом, точне визначення дати й години його початку та його закінчення, а також точний проміжок часу переходу на бік ворога) стороною обвинувачення не встановлено». Захисники вважають, що судом надано неправильну оцінку юридичним поняттям, прирівнявши термін «збройна агресія» до терміна «збройний конфлікт», що, на переконання захисту, є неприпустимим. Зокрема «законодавець у диспозиції ст. 111 КК України прирівнює воєнний стан до збройного конфлікту, однак поняття «збройний конфлікт» має самостійне правове значення для кваліфікації ст. 111 КК, якщо такий конфлікт відбувається поза межами воєнного стану, - у разі фактичного початку воєнних (збройних) дій і в контексті ст. 111 КК України, - це поняття $\epsilon$ юридичним синонімом до поняття «бойова обстановка» тощо [4].

Нагадаємо, що термін «збройний конфлікт» внесений у міжнародне право після Другої світової війни. Він міститься у всіх чотирьох Женевських конвенціях про захист жертв війни від 12 серпня 1949 р. Однак визначення військового конфлікту чи війни у міжнародно-правових актах відсутнє. Стаття 3 Женевських конвенцій не роз'яснює поняття «військовий конфлікт, який не носить міжнародного характеру». Стаття 2 Женевських конвенцій містить поняття міждержавного військового конфлікту, який включає всі випадки «оголошеної війни чи будь-якого іншого збройного конфлікту, що може виникнути між двома чи більше Високими Договірними 
Сторонами, навіть якщо стан війни не визнаний однією з них» [5]. Відповідно до коментарю Міжнародного комітету Червоного Хреста та Женевськими конвенціями «будь-яка суперечка, яка виникає між двома державами та призводить до дій осіб із складу збройних сил, є збройним конфліктом за смислом статті 2. ... Не має значення, як довго продовжується конфлікт, або який масштаб кровопролиття, або яка чисельність сил, які беруть участь; достатньо, щоб збройні сили однієї держави захопили супротивників, які підпадають до сфери дії статті 4. Навіть якщо не було жодних боїв, той факт, що особи, про які йдеться в Конвенції, були затримані, $є$ достатнім для його застосування» [6].

Законодавство України розкриває поняття збройного конфлікту у Військовій доктрині України, яка затверджена Указом Президента України № 555/2015 від 24 вересня 2015 року [7] та Законі України від 21 червня 2018 р. «Про Національну безпеку України» [8]. Так п.7 ст.1 Закону розкриває поняття збройного конфлікту як збройне зіткнення між державами (міжнародний збройний конфлікт, збройний конфлікт на державному кордоні) або між ворогуючими сторонами в межах території однієї держави, як правило, за підтримки ззовні (внутрішній збройний конфлікт). Факт міжнародного збройного конфлікту між Україною та Російською Федерацією на території Автономної Республіки Крим підтверджується низкою нормативно-правових актів. 4 листопада 2014 р. Верховною Радою України прийнято Закон України «Про забезпечення прав і свобод громадян та правовий режим на тимчасово окупованій території України» [9].

Закон визначив статус Автономної Республіки Крим та м. Севастополя, а також внутрішні води України цих територій як тимчасово окуповані внаслідок військової агресії Російської Федерації. Встановлена дата окупації - 20 лютого 2014 р. Слід також враховувати положення Резолюції Генеральної Асамблеї ООН «Про територіальну цілісність України» № 68/262 від 27 березня 2014 р., які підкреслюють нелегітимність проведення в Автономній Республіці Крим референдуму та закликають міжнародну спільноту не визнавати будьяку зміну статусу Автономної Республіки Крим та м. Севастополь на підставі результатів зазначеного референдуму, а також резолюції Генеральної Асамблеї Організації Об’єднаних Націй «Стан справ у сфері прав людини в Автономній Республіці Крим та місті Севастополі (Україна)» № 71/205 від 19 грудня 2016 року та № 72/190 від 19 грудня 2017 року, які визнають Автономну Республіку Крим та місто Севастополь територією, тимчасово окупованою Російською Федерацією.

Особливу важливість має оцінка подій у Криму, яка проведена Канцелярією Прокурора Міжнародного кримінального суду за результатами попереднього розслідування. Воно було розпочато 25 квітня 2014 р. після подання урядом України декларації, яка визнає 
юрисдикцію Суду стосовно злочинів, які вчинені на території України. 14 листопада 2016 р. канцелярія Прокурора надала звіт про дії по попередньому розслідуванню за 2016 р. У документі ситуація на території Криму та Севастополя кваліфіковані як міжнародний збройний конфлікт між Україною та Російською Федерацією, який виник не пізніше ніж 26 лютого 2014 р. Згідно з оцінкою Прокурора, до ситуації в Криму залишається застосованим право міжнародних збройних конфліктів і після 18 березня 2014 р., через те що в Криму та Севастополі фактично зберігається стан окупації [10]. Незважаючи на попередній характер наведеної оцінки, у ній визначається правова основа для поточного аналізу інформації про злочини, які, скоріше за все, вчинені в контексті ситуації в Криму в період з 20 лютого 2014 р.

Прокурором Міжнародного кримінального суду звертається увага на те, що встановлення факту правомірності початкової інтервенції Російської Федерації, яка спричинила за собою окупацію, не вимагається. Для цілей Римського статуту збройний конфлікт може бути міжнародним за своєю сутністю, якщо одна або кілька держав частково або повністю окупують територію іншої держави незалежно від того, чи супроводжується окупація збройним супротивом. 05 грудня 2018 р. Канцелярія Прокурора надала звіт по попередньому розслідуванню цього конфлікту за 2018 р., який містить висновки, що ідентичні звіту за 2016 р. [11]. Звертає на себе увагу той факт, що вже через два дні після публікації канцелярією Прокурора Міжнародного кримінального суду звіту про події в Криму, Президент Російської Федерації 16 листопада 2016 р. підписав розпорядження «Про наміри Російської Федерації не стати учасником Римського Статуту Міжнародного кримінального суду» [12].

Більш дискусійним є питання визнання наявності міжнародного збройного конфлікту на сході України. Згідно із ст.1 Закону України № 2268-VIII від 18 січня 2018 р. «Про особливості державної політики із забезпечення державного суверенітету України на тимчасово окупованих територіях у Донецькій та Луганській областях» [13] «тимчасово окупованими територіями у Донецькій та Луганській областях на день ухвалення цього Закону визнаються частини території України, у межах яких збройні формування Російської Федерації та окупаційна адміністрація Російської Федерації встановили та здійснюють загальний контроль». «Межі та перелік районів, міст, селищ і сіл, частин їх територій, тимчасово окупованих у Донецькій та Пуганській областях, визначаються Президентом України за поданням Міністерства оборони України, підготовленим на основі пропозицій Генерального штабу Збройних Сил України». У преамбулі зазначеного Закону вказано, що дії Російської Федерації на території окремих районів Донецької та Луганської областей, Автономної Республіки Крим та міста Севастополя грубо порушують принципи та норми міжнародного права. Зазначається також про таке: 1) систематичне недотримання режиму припинення вогню і продовження обстрілів 
цивільних об'єктів та інфраструктури, що спричиняють численні жертви серед цивільного населення, військовослужбовців Збройних Сил України та інших утворених відповідно до законів України військових формувань; 2) продовження практики протиправного затримання й утримання громадян України на тимчасово окупованих територіях, їх незаконного вивезення та утримання на території Російської Федерації; 3) намагань поширити російське законодавство, у тому числі податкове, на території окремих районів Донецької та Луганської областей, Автономної Республіки Крим та міста Севастополя, висування незаконних вимог щодо перереєстрації підприємств та стягнення коштів на користь окупаційної адміністрації Російської Федерації в окремих районах Донецької та Луганської областей, в Автономній Республіці Крим та місті Севастополі; 4) запровадження російського рубля як єдиної валюти на території окремих районів Донецької та Луганської областей, Автономної Республіки Крим та міста Севастополя; 5) свавільного застосування російських освітніх стандартів у навчальних закладах, запровадження на підприємствах в окремих районах Донецької та Луганської областей, в Автономній Республіці Крим та місті Севастополі «зовнішнього управління» та визнання незаконних ідентифікаційних документів та реєстраційних знаків транспортних засобів на території окремих районів Донецької та Луганської областей, Автономної Республіки Крим та міста Севастополя; 6) організації та здійснення насильницьких зникнень, катувань, нелюдського поводження або покарання, позасудових страт стосовно цивільного населення, українських військовослужбовців та заручників тощо.

Таким чином, законодавством України визначено, що окремі райони Донецької та Луганської областей України є тимчасово окупованими, але не встановлено що це здійснено саме Російською Федерацією. Ідеться тільки про «загальний контроль», який установлений та здійснюється збройними формуваннями Російської Федерації та окупаційною адміністрацією Російської Федерації. Через такий гібридний характер окупації жодного вироку в Єдиному державному реєстрі судових рішень України за перехід на бік ворога під час збройного конфлікту на сході України в період 2014-2018 рр. немає. Навіть навпаки, є випадки виправдовувальних вироків.

Так 22 листопада 2018 року колегія суддів судової палати з розгляду кримінальних справ Запорізького апеляційного суду розглянула апеляційну скаргу прокурора на вирок суду першої інстанції, яким виправдано військовослужбовця Збройних Сил України за ст.111 КК України. Зокрема він під час виконання бойових завдань був 28 серпня 2014 р. захоплений у полон військовослужбовцями Збройних сил Російської Федерації. Надалі разом з іншими полоненими переданий представникам терористичної організації «ДНР», де утримувався ними в подальшому. Перебуваючи в полоні, цей військовослужбовець у 
жовтні 2014 р. добровільно вступив до складу терористичної організації «ДНР», був забезпечений військовою формою одягу з Георгіївською стрічкою та шевроном «Новороссия», а також автоматичною вогнепальною зброєю - автоматом АК-74. Надалі він був включений до складу озброєного підрозділу терористичної організації «ДНР», а саме «1-ї окремої мотострілецької бригади, яка також має назву «Перша Слов'янська бригада» [14]. На думку прокурора, перехід громадянина України на бік ДНР, яка є підконтрольною Російській Федерації, слід вважати таким, що відбувся під час збройного конфлікту, і відповідно повинен кваліфікуватися як державна зрада. У свою чергу колегія апеляційного суду підтримала позицію суду 1 інстанції щодо відсутності в діях військовослужбовця ознак державної зради. У судовому рішенні зазначено, що територія Донецької та Луганської областей відповідно до змісту Закону України «Про забезпечення прав і свобод громадян та правовий режим на тимчасово окупованій території України» не мають статусу тимчасово окупованих Російською Федерацією. Крім того, колегія суддів звернула увагу на сутність «Донецької народної республіки» як терористичної організації, яка не містить жодних ознак, притаманних державі. Вказане «утворення» не визнається як держава ані Україною, ані будь-якими іншими державами або міжнародними організаціями. 3 огляду на викладене, твердження прокурора, що військовослужбовець перейшов на бік ворога, яким за конструкцією ч. 1 ст. 111 КК України може бути лише інша держава або державне утворення, $є$ безпідставним i помилковим. Також апеляційним судом було звернено увагу на відсутність доказів, які б вказували й на те, що підсудний перейшов на бік Російської Федерації, з якою Україна офіційно, з урахуванням вимог міжнародних конвенцій, не перебуває ані в стані війни, ані в стані збройного конфлікту [15]. Зазначене судове рішення є показовим і свідчить про різну правову оцінку подіям на території Автономної Республіки Крим та на території Донецької і Луганської областей. У першому випадку йдеться про міжнародний збройний конфлікт між Україною та Російською Федерацією, а у другому - про діяльність терористичних організацій, які діють під контролем та за підтримки Російської Федерації. Судова практика застосовує підхід щодо кваліфікації дій громадян України по переходу на бік так званих «ДНР» та «ЛНР» саме за ч. 1 ст. 258-3, як участь у терористичній організації [16].

Збройний конфлікт на сході України є предметом вивчення Канцелярією Прокурора Міжнародного кримінального суду, яка за результатами попереднього розслідування опублікувала звіт за 2016 р. У висновках зазначається, що до 30 квітня 2014 року інтенсивність бойових дій між українськими урядовими військами й антиурядовими озброєними елементами на сході України досягла такого рівня, який тягне за собою можливість застосування до нього права збройних конфліктів, і що озброєні групи, які діють на сході України, у тому числі «ЛНР» та «ДНР», достатньо організовані, щоб розглядатися як сторони 
неміжнародного збройного конфлікту. Канцелярія Прокурора також прийшла до висновку, що приклади прямого збройного протистояння між збройними силами Російської Федерації та України вказують на те, що принаймні з 14 липня 2014 року на сході України, паралельно із неміжнародним збройним конфліктом, має місце міжнародний збройний конфлікт. Канцелярія Прокурора продовжує розглядати заяви про те, що Російська Федерація здійснювала та здійснюе загальний контроль над озброєними групами на сході України, щоб встановити чи можна розглядати збройний конфлікт між Збройними Силами України та антиурядовими озброєними групами, як, по суті, міжнародний конфлікт. Факт існування єдиного міжнародного збройного конфлікту на сході України передбачає застосування стосовно відповідного періоду статей Статуту, який стосується збройних конфліктів міжнародного характеру. Тобто, на сьогодні Канцелярія Прокурора розглядає альтернативу щодо визначення збройного конфлікту /тів на сході України для впровадження положень Римського статуту, які застосовані до конфліктів як міжнародного, так i не міжнародного типу [10]. Так 05 грудня 2018 р. Канцелярія Прокурора надала звіт щодо попереднього розслідування конфлікту на сході України за 2018 р., який містить висновки, що ідентичні звіту за 2016 p. [11]

Висновки. Отже, правова оцінка збройного конфлікту на сході України ускладнена публічним (офіційним) категоричним невизнанням Російською Федерацією факту застосування власних Збройних Сил на території окремих районів Донецької та Луганської областей $[17,18]$. Через те що російська сторона не визнає своєї участі в конфлікті, факт здійснення нею контролю над збройними формуваннями самопроголошених республік має бути доведений Україною на рівні міжнародних судових інстанцій, на противагу із ситуацією в Криму [19, с.4]. Таким чином, для кваліфікації дій громадян України, які перейшли на бік ворога під час збройного конфлікту за ст.111 КК України, розпочатого ще в 2014 році на сході України, визначальним стануть висновки Міжнародного кримінального суду по визнанню або невизнанню зазначеного збройного конфлікту міжнародним (між Україною та Російською Федерацією). Отож ситуація на території Криму та Севастополя, згідно із національним законодавством України, Резолюціями Генеральної Асамблеї ООН та висновками Канцелярії Прокурора Міжнародного кримінального суду за результатами попереднього розслідування, оцінюється як міжнародний збройний конфлікт між Україною та Російською Федерацією, який виник 20 лютого 2014 р. та продовжується до сьогодні як окупація півострова та його внутрішніх вод. Така оцінка надає підстави кваліфікувати дії громадян України по переходу на бік ворога за ст. 111 КК України «Державна зрада», як вчинені саме в період збройного конфлікту. 


\section{Використані джерела:}

1. За 10 років в Україні за державну зраду засудили 7 людей. 28.04.2012. URL: http:/ / tyzhden.ua/News/48897 (дата: 10.04.2019).

2. Піти наліво від країни: кого і як звинувачують у державній зраді в Україні. 09.12.2016. URL: https://daily.rbc.ua/ukr/show/uyti-nalevo-stranykogo-obvinyayut-gosudarstvennoy-1481276999.html (дата: 10.04.2019).

3. Єдиний звіт про крим. правопорушення за січень-грудень 2018p.: офіційний веб-сайт Ген. прокуратури України. URL: https:// www.gp.gov.ua/ua/stst2011.html?dir_id=113281\&libid=100820\# (10.04.2019).

4. Ухвала колегії суддів судової палати з розгляду кримінальних справ Апеляційного суду м. Києва від 25.06.2018 у справі № 11-кп/796/431/2018. URL: http:/ / reyestr.court.gov.ua/Review/75004486 (дата: 10.04.2019).

5. Женевська конвенція про поводження 3 військовополоненими від 12.08.1949. URL: https://zakon.rada.gov.ua/laws/show/995_153 (дата: 10.04.2019).

6. Паулюс А., Вашакмадзе М. Ассиметричная война и понятие вооруженного конфликта - попытка разработать концептуальную модель. URL: https://www.icrc.org/ru/doc/assets/files/other/paulus.pdf (дата: 10.04.2019).

7. Про рішення Ради національної безпеки і оборони України від 02.09.2015 року «Про нову редакцію Воєнної доктрини України» № 555/2015 від 24.09.2015p. URL: https://zakon.rada.gov.ua/laws/show/555/2015 (дата: 10.04.2019).

8. Про Національну безпеку України: Закон України від 21.06.2018p. 2469-VIII. URL: https://zakon.rada.gov.ua/laws/show/2469-19\#n355 (дата: 10.04.2019).

9. Про забезпечення прав і свобод громадян та правовий режим на тимчасово окупованій території України. URL: https:/ / zakon.rada.gov.ua/laws/show/1207-18 (дата: 10.04.2019).

10. Отчет о действиях по предварительному расследованию за $2016 г$. Канцелярия Прокурора Международного уголовного суда. 14.11.2016 г. URL: https://www.icc-cpi.int/iccdocs/otp/161114-otp-rep-PE-Ukraine.pdf (дата: 10.04.2019).

11. Отчет о действиях по предварительному расследованию за 2018г. Канцелярия Прокурора Международного уголовного суда. 05.12.2018г. URL: https://www.icc-cpi.int/itemsDocuments/2018-otp-rep-PE Ukraine.pdf (дата: 10.04.2019).

12. Россия вышла из Международного уголовного суда. Интерфакс. 16.11.2016. URL: https://www.interfax.ru/russia/537268 (дата: 10.04.2019).

13. Про особливості державної політики із забезпечення державного суверенітету України на тимчасово окупованих територіях у Донецькій та Луганській областях. URL: https://zakon.rada.gov.ua/laws/show/2268-19 (дата: 10.04.2019).

14. Вирок Куйбишевського районного суду Запорізької області від 15.11.2017 у справі № 319/85/17. URL: http:/ / reyestr.court.gov.ua/Review/70280831 (дата: 10.04.2019). 
15. Ухвала колегії суддів судової палати з розгляду кримінальних справ Запорізького апеляційного суду від 22.11.2018 у справі № 319/85/17. URL: http:/ / reyestr.court.gov.ua/Review/78161951 (дата: 10.04.2019).

16. Український суд засудив до в'язниці екс-главу міліції Маріуполя, який перейшов на бік бойовиків ДНР. 30.08.2017. URL: https://apostrophe.ua/ua/news/politics/judiciary/2017-08-30/ukrainskij-sud prigovoril-k-tyurme-eksglavu-milicii-mariupolya-kotoryj-pereshel-na-storonuboevikov-dnr-foto/105689

17. Наших войск там нет, - Путин в очередной раз цинично солгал о Донбассе. 07.03.2018. URL: https://24tv.ua/ru/nashih_vojsk_tam_net_putin_v_ocherednoj_raz_cinich no_solgal_o_donbasse_n935358 (дата: 10.04.2019).

18. Волкер: Пока РФ не признает свое присутствие на Донбассе, ситуация не сдвинется 24.01.2018. URL: https://www.ukrinform.ru/rubricpolytics/2389062-volker-poka-rf-ne-priznaet-svoe-prisutstvie-na-donbassesituacia-ne-sdvinetsa.html (дата: 10.04.2019).

19. Збройний конфлікт в Україні: військова підтримка незаконних збройних формувань «ДНР» та «ЛНР» 3 боку Російської Федерації / О. Гарбар, А. Конопкін, О. Кореньков, С. Мовчан, За ред.: О. Павліченка, О. Мартиненка / Українська Гельсінська спілка з прав людини. - К., 2018. - 40 с.

\section{References:}

1. Za 10 rokiv v Ukraini za derzhavnu zradu zasudyly 7 liudei. 28.04.2012. URL: http:/ / tyzhden.ua/News/48897 [in Ukrainian].

2. Pity nalivo vid krainy: koho i yak zvynuvachuiut $\mathrm{u}$ derzhavnii zradi $\mathrm{v}$ Ukraini. 09.12.2016. URL: https://daily.rbc.ua/ukr/show/uyti-nalevo-stranykogo-obvinyayut-gosudarstvennoy-1481276999.html [in Ukrainian].

3. Yedynyi zvit pro krym. pravoporushennia za sichen-hruden 2018r.: ofitsiinyi vebsait Hen.prokuratury Ukrainy.URL :https:/ / www.gp.gov.ua/ua/ stst2011.html?dir_id=113281\&libid=100820\# [in Ukrainian]. Ukhvala kolehii suddiv sudovoi palaty z rozghliadu kryminalnykh sprav

4. Apeliatsiinoho sudu $\mathrm{m}$. Kyieva vid 25.06.2018 u spravi № 11kp/796/431/2018 URL: http:// reyestr.court.gov.ua/Review/75004486 [in Ukrainian].

5. Zhenevska konventsiia pro povodzhennia $\mathrm{z}$ viiskovopolonenymy vid 12.08.1949. URL: https://zakon.rada.gov.ua/laws/show/995_153 [in Ukrainian].

6. Paulius A., Vashakmadze M. Assimetrichnaia voina i poniatie vooruzhennogo konflikta - popytka razrabotat kontceptualnuiu model. URL: https://www.icrc.org/ru/doc/assets/files/other/paulus.pdf [in Russian].

7. Pro rishennia Rady natsionalnoi bezpeky i oborony Ukrainy vid 02.09.2015 r «Pro novu redaktsiiu Voiennoi doktryny Ukrainy» № 555/2015. [On the decision of the National Security and Defense Council of Ukraine «On the new version of the Military Doctrine of Ukraine»] (n.d.). zakon.rada.gov.ua. URL: https://zakon.rada.gov.ua/laws/show/555/2015 [in Ukrainian].

8. «Pro Natsionalnu bezpeku Ukrainy»: Zakon Ukrainy vid 21.06.2018 r. № 2469 VIII. [The Law of Ukraine «On the Ukraine's national security»] (n.d.). zakon.rada.gov.ua. URL: https://zakon.rada.gov.ua/laws/show/2469-19\#n355 [in Ukrainian]. 
9. «Pro zabezpechennia prav i svobod hromadian ta pravovyi rezhym na tymchasovo okupovanii terytorii Ukrainy»: Zakon Ukrainy vid 15.04.2014 r. № 1207- VII . [The Law of Ukraine « On ensuring the rights and freedoms of citizens and the legal regime in the temporarily occupied territory of Ukraine»] (n.d.). zakon.rada.gov.ua. URL: https://zakon.rada.gov.ua/laws/show/1207-18 [in Ukrainian].

10. Otchet o deistviiakh po predvaritelnomu rassledovaniiu za $2016 \mathrm{~g}$. Kantceliariia Prokurora Mezhdunarodnogo ugolovnogo suda. 14.11.2016 g. URL: https://www.icc-cpi.int/iccdocs/otp/161114-otp-rep-PE-Ukraine.pdf [in Russian].

11. Otchet o deistviiakh po predvaritelnomu rassledovaniiu za $2018 \mathrm{~g}$. Kantceliariia Prokurora Mezhdunarodnogo ugolovnogo suda. 05.12.2018 g. URL: https://www.icc-cpi.int/itemsDocuments/2018-otp-rep-PE-Ukraine.pdf [in Russian].

12. Rossiia vyshla iz Mezhdunarodnogo ugolovnogo suda. Interfaks. 16.11.2016. URL: https://www.interfax.ru/russia/537268 [in Russian].

13. «Pro osoblyvosti derzhavnoi polityky iz zabezpechennia derzhavnoho suverenitetu Ukrainy na tymchasovo okupovanykh terytoriiakh u Donetskii ta Luhanskii oblastiakh»: Zakon Ukrainy vid 18.01.2018. № 2268-VIII. [The Law of Ukraine «On the features of state policy for ensuring state sovereignty of Ukraine in temporarily occupied territories in Donetsk and Luhansk Regions»] (n.d.). zakon.rada.gov.ua. URL: https://zakon.rada.gov.ua/laws/show/2268-19 [in Ukrainian].

14. Vyrok Kuibyshevskoho raionnoho sudu Zaporizkoi oblasti vid 15.11.2017 u spravi № 319/85/17. URL: http:// reyestr.court.gov.ua/Revi ew/70280831 [in Ukrainian].

15. Ukhvala kolehii suddiv sudovoi palaty $\mathrm{z}$ rozghliadu kryminalnykh sprav Zaporizkoho apeliatsiinoho sudu vid 22.11.2018 u spravi № 319/85/17. URL: http:// reyestr.court.gov.ua/Review/78161951 [in Ukrainian].

16. Ukrainskyi sud zasudyv do v'iaznytsi eks-hlavu militsii Mariupolia, yakyi pereishov na bik boiovykiv DNR. 30.08.2017. URL: https:/ / apostrophe.ua/ua/news/ politics/judiciary/2017-08-30/ukrainskijsud-prigovoril-k-tyurme-eksglavu-milicii-mariupolya-kotoryj-pereshel-nastoronu-boevikov-dnr-foto/105689 [in Ukrainian].

17. Nashikh voisk tam net, - Putin v ocherednoi raz tcinichno solgal o Donbasse. 07.03.2018.URL: https://24tv.ua/ru/nashih_vojsk_tam_net_p utin_v_ocherednoj_raz_cinichno_solgal_o_donbasse_n935358 [in Russian].

18. Volker: Poka RF ne priznaet svoe prisutstvie na Donbasse, situatciia ne sdvinetsia. 24.01.2018. URL: https://www.ukrinform.ru/rubricpolytics / 2389062-volker-poka-rf-ne-priznaet-svoe-prisutstvie-na-donbassesituacia-ne sdvinetsa.html [in Russian].

19. Harbar O., Konopkin A., Korenkov O., Movchan S. (2018). Zbroinyi konflikt v Ukraini: viiskova pidtrymka nezakonnykh zbroinykh formuvan «DNR» ta «LNR» z boku Rosiiskoi Federatsii. Kyiv: Ukrainska Helsinska spilka z prav liudyny [in Ukrainian]. 
Зайцев А. В.,

кандидат юридических наук, доцент, доцент кафедры уголовного права №1 Национального юридического университета имени Ярослава Мудрого

(г. Харьков, Украина)

\title{
К ПРОБЛЕМЕ КВАЛИФИКАЦИИ ГОСУДАРСТВЕННОЙ ИЗМЕНЫ ПРИ ПЕРЕХОДЕ НА СТОРОНУ ВРАГА В ПЕРИОД ВООРУЖЕННОГО КОНФЛИКТА (АНАЛИЗ СУДЕБНОЙ ПРАКТИКИ 2014-2018 ГГ.)
}

\begin{abstract}
Статья посвящена исследованию проблемы квалификации государственной измены при переходе на сторону врага в период вооруженного конфликта. Изучено судебную практику за 2014-2018 гг. Сделан вывод о различной законодательной оценке оккупации Автономной Республики Крым и отдельных районов Донецкой и Луганской областей. Обосновывается различная уголовноправовая квалификация действий по переходу на сторону врага во время этих вооруженных конфликтов. Акцентируется внимание на выводах, которые содержатся в отчетах по результатам предварительного расследования событий в Крыму и на востоке Украины, опубликованных в 2016 г. и 2018 г. Канцелярией Прокурора Международного уголовного суда.
\end{abstract}

Ключевые слова: переход на сторону врага, вооруженный конфликт, Международный уголовный суд.

Zaytsev O.,

candidate of law, associate professor, associate professor of the department of criminal law № 1

National law university named after Yaroslav Mudriy

(Kharkov, Ukraine)

\section{TO THE PROBLEM OF QUALIFICATION OF STATE TREASON IN THE EVENT OF THE TRANSITION TO THE ENEMY DURING THE ARMED CONFLICT (THE ANALYSIS OF JUDICIAL PRACTICE 2014-2018)}

The article focuses on the problem of qualification of a treason in the event of siding with the enemy during the armed conflict. Since 2004 there has been a sharp increase in the number of criminal proceedings under art. 111 of the Criminal Code of Ukraine "Treason". The judicial practice is examined from 2014 to 2018. It was considered that legislative assessment of the occupation of the Autonomous Republic of Crimea and certain areas of Donetsk and Luhansk region differs a lot.

On the results of the preliminary investigation, the national legislation of Ukraine, the UN General Assembly Resolution and the conclusions of the Office of the Prosecutor of the International Criminal Court allow us to assess the situation in Crimea and Sevastopol as an international armed conflict between Ukraine and the Russian Federation, which arose on 20 February 2014 and continues to this day, while the peninsula and its inland waters are still being occupied. It gives grounds to qualify the actions of Ukrainian citizens under the article 111 of the Criminal Code of Ukraine in case of siding with the enemy during the armed conflict. 
Ukrainian legislation assesses temporary occupation of certain areas of Donetsk and Lugansk regions of Ukraine differently. There has been only "overall control», which is established and carried out by armed groups and occupying administration of the Russian Federation. This causes the absence of convictions for the siding with the enemy during the armed conflict in eastern Ukraine in the period from 2014 to 2018. The situation with the legal assessment of the armed conflict in eastern Ukraine is becoming more complex, because the Russian Federation failures to acknowledge publicly and officially that they use their own armed forces on the territory of certain areas of Donetsk and Luhansk regions. That is, in order to qualify under article 11.1 of the Criminal Code of Ukraine, concerning the actions of Ukrainian citizens who have sided with the enemy during the armed conflict, which has began in 2014 in the east of Ukraine, the opinion of the International Criminal Court will be the decisive factor in the recognition or nonrecognition of the stated armed conflict as international (between Ukraine and the Russian Federation). Court.

Key words: event of siding with the enemy, armed conflict, International Criminal

DOI

УДК 343.9

I. О. Іерусалімов, кандидат юридичних наук, доцент, професор кафедри досудового розслідування Національної академії внутрішніх справ (м. Київ, Україна) e-mail: igor.ierusalimov@gmail.com iD https:/ / orcid.org/0000-0003-3163-982X

O. I. Литвинчук, кандидат юридичних наук, доцент, адвокат, доцент кафедри досудового розслідування, Національної академії внутрішніх справ (м. Київ, Україна) e-mail: litvinchuke@gmail.com iDhttps://orcid.org/0000-0003-3884-8595

В. I. Ієрусалимов, аспірант приватного вищого навчального закладу «Европейський університет» (м. Київ, Україна) e-mail: ierusalimov.vlad@gmail.com iD https://orcid.org/0000-0003-1534-303

\section{ІСТОРИЧНО-ПРАВОВІ АСПЕКТИ ПРОТИДІЇ НАСИЛЬСТВУ В СІМ'Ї}

Статтю присвячено дослідженню історично-правових аспектів протидії насильства в сім'ї. У роботі розкрито причини виникнення насильства в сім'ї, які знаходяться в історичній, культурній та соціальній площині.

Надано детальну хронологію розвитку боротьби за права жінок та протидії домашньому насильству на рівні ООН, включаючи перелік конференцій та

(C) Іерусалимов I. О., Литвинчук О. I. 269

Іерусалимов В. І., 2019 